\author{
桜 庭 正 則*・岩 野

\section{Current Plant Practice and Prospect of Kuroko Processing}

\section{Masanori SAKURABA and Kazu IWANO}

和**

\section{1. は じめに}

花岡鉱山では, かつては松峰選鉱工場および堂屋敷選 鉱工場において鉱石を処理していたが，昭和59年以降の 円高に対処して操業規模の縮小を行い, 昭和61年堂屋敷 選鉱工場を閉鎖し，選鉱処理を松峰選鉣工場に集約した。 現在, 松峰選鉱工場では松峰鉱, 深沢鉱および温川鉱の 混合処理を行い, 順調に稼働している。

温川鉱山は昭和 62 年に開山し, 当初は粗鉱を内の岱選 鉱工場に送鉱していた。その後, 内の岱鉱床の終掘に伴 い, 平成 3 年に内の岱選鉱工場が閉鎖されたため, 現在 温川鉱は，松峰選鉱工場にトラック翰送されている。

一方海外では，本年 5 月よりメキシコにおいて，黒鉱 で蓄積された選鉱技術を応用し新鉱山の開発に取り組ん でいる。本報では, 温川鉱の混合処理を開始した松峰選 鈗工場の現況と, メキシュのティサパ鉱山開発の概要に ついて報告する。

\section{2. 操 業 概 要}

松峰選鉱工場では, 現在松峰鉱 $13,000 \mathrm{~T} /$ 月, 深沢鉱 $16,500 \mathrm{~T} /$ 月, 温川鉱 $3,800 \mathrm{~T} /$ 月, 合計 $33,300 \mathrm{~T} /$ 月を 13 日操業で処理している。
平成 4 年度上期生産計画を第 1 表に，平成 4 年度上期 人員計画を第 2 表に示した。

\section{1 受け入れ，破砕工程}

受け入れは，鉱山毎に品位，鉱量を管理するため鉱種 別に行っている。松峰鉱, 深沢鉱は坑内で $-100 \mathrm{~mm}$ に 一次破砕され，松峰鉱はベルトコンベアで，深沢鉱はト ラックでストックヤードに運搬される。一方温川鉱は, 粗鉱の状態でトラックにより松峰に運搬された後, スト ックヤードで $-100 \mathrm{~mm}$ に一次破砕される。その後各鉱 石は, ローダー, パンュンベア，ベルトコンベアで破砕 工場に搬送され，ドラムスクラバーで水洗後，スクリー ンでふるい分けされる。塊鉱はジャイレトリークラッシ ャーとコーンクラッシャーにより，2段で破砕される が，ジャイレトリークラッシャーは開回路で，コーンク ラッシャーは閉回路で処理し, 最終産物は $-25 \mathrm{~mm}$ と なる。スクリーンでふるい分けされた $-3 \mathrm{~mm}$ の鉱石は, エーキンス分級機とサイクロンによりサンドとスライム に分級される。サンドはエキストラクターで脱水後, 塊 鉱の最終産物と共にミルビンに送られ，スライムはスラ イムシックナーに送られる。破砕工程のフローシートを 第 1 図に示した。

\section{2 碞鉱工程}

第 1 衰 平成 4 年上期処理計画

\begin{tabular}{|c|c|c|c|c|c|c|c|c|c|c|c|c|c|c|c|c|}
\hline \multirow{2}{*}{ 稀 䅱 } & \multirow{2}{*}{ 话 口 } & \multirow{2}{*}{ 歩 付 } & \multicolumn{7}{|c|}{ 品 } & \multicolumn{4}{|c|}{ 分 } & \multicolumn{3}{|c|}{ 率 （\%) } \\
\hline & & & A $u$ & A $g$ & C u & $\mathrm{P} \quad \mathrm{b}$ & $\mathrm{Z} n$ & P y S & $\mathrm{BaSO}_{4}$ & A $\mathrm{u}$ & A $\mathrm{g}$ & $\mathrm{C} \quad \mathrm{u}$ & $\mathrm{P} \quad \mathrm{b}$ & $\mathrm{Zn}$ & P y $S$ & $\mathrm{BaSO}_{4}$ \\
\hline 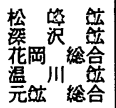 & \begin{tabular}{|r|}
13,000 \\
16,500 \\
29,500 \\
3,800 \\
33.300
\end{tabular} & $\begin{array}{r}39.0 \\
49.5 \\
88.6 \\
11.4 \\
100.0\end{array}$ & $\begin{array}{l}0.70 \\
0.50 \\
0.59 \\
2.40 \\
0.79\end{array}$ & $\begin{array}{r}75.0 \\
80.0 \\
77.8 \\
148.0 \\
85.8\end{array}$ & $\begin{array}{l}2.60 \\
0.85 \\
1.62 \\
1.51 \\
1.61\end{array}$ & $\begin{array}{l}1.25 \\
2.55 \\
1.98 \\
6.02 \\
2.44\end{array}$ & $\begin{array}{l}3.60 \\
9.00 \\
6.62 \\
9.89 \\
6.99\end{array}$ & $\begin{array}{r}20.00 \\
5.50 \\
11.89 \\
5.42 \\
11.15\end{array}$ & $\begin{array}{l}7.00 \\
8.00 \\
7.56 \\
3.11 \\
7.05\end{array}$ & $\begin{array}{r}34.38 \\
31.17 \\
65.55 \\
34.45 \\
100.00\end{array}$ & $\begin{array}{r}34.12 \\
46.20 \\
80.32 \\
19.68 \\
100.00\end{array}$ & $\begin{array}{r}63.10 \\
26.18 \\
89.28 \\
10.72 \\
100.00\end{array}$ & $\begin{array}{r}20.01 \\
51.82 \\
71.83 \\
28.17 \\
100.00\end{array}$ & $\begin{array}{r}20.01 \\
63.77 \\
83.87 \\
16.13 \\
100.00\end{array}$ & $\begin{array}{r}70.02 \\
24.44 \\
94.46 \\
5.54 \\
100.00\end{array}$ & $\begin{array}{r}38.75 \\
56.21 \\
94.96 \\
5.04 \\
100.00\end{array}$ \\
\hline
\end{tabular}

平成 4 年11月19日本会第89回例会において発表

* 花岡鉱業株式会社鉱山部

** 同和鈗業株式会社資源開発事業部 平成 4 年10月 9 日受理
第 2 表 平成 4 年上期人員配置

\begin{tabular}{|c|c|c|c|c|c|c|c|}
\hline 㽣名 & 破碀 & 摩航 - 浮選 & 精鉣 & 共通 & 小計 & 躘員 & 合計 \\
\hline 人且 & 4 & 7 & 4 & 1 & 16 & 7 & 23 \\
\hline
\end{tabular}




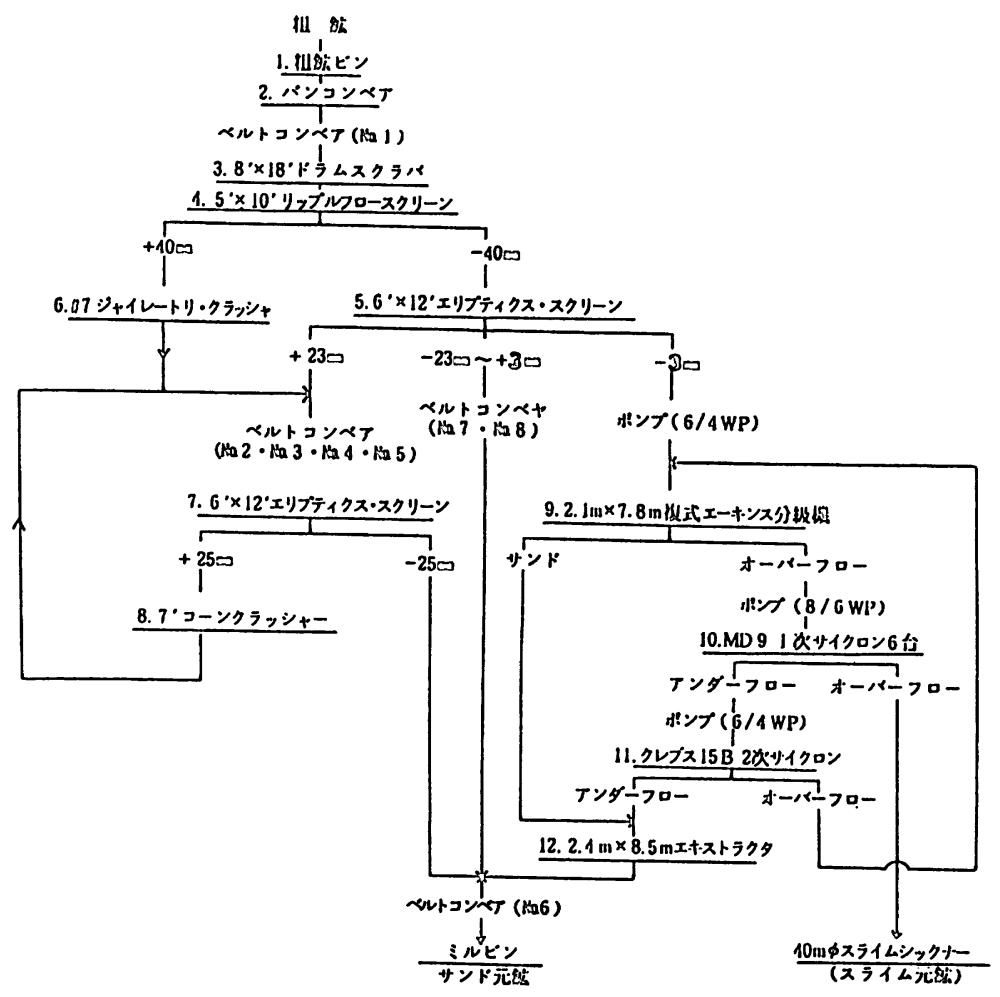

第 1 図破砕系統図

ミルビンから抜き出された鉱石は、コンスタントフ ィーダーによりロッドミルに定量給鉱されている。磨鉱 は, ロッドミル 1 台とボールミル 2 台により 3 段階で行 っている。ロッドミルは開回路で，ボールミルはサイク ロンによる 2 段分級と組み合わせた閉回路でそれぞれ磨 鉱を行っている。浮選給鉱サイズの管理目標は, -200 mesh 65\%としている。このサイズを維持するために, サイクロンフィードのポンプの回転数を自動調節し, サ イクロンフィード圧を制御している。

\section{3 浮選工程}

浮選は, 亜硫酸一消石灰による銅一鉛セミバルク浮選, およびその後は, 亜鉛一硫化鉄一重晶石の直接榎先浮選 方式を採用している。

銅一鉛セミバルク浮選では，再磨鉱を含め 3 次精選ま で行っている。銅一鉛分離系では, 温水 (温度 $65^{\circ} \mathrm{C}$ ) で分離浮選を行っており，浮鉱は銅精鉱となる。沈鉱は 更に脱 $\mathrm{Zn}$ 浮選を行い，鉛品位の向上を図った上，鉛精 鉱としている。また 2 次銅鉱物が増加し，鉛精鉱中の銅 品位が上昇した場合，脱銅浮選系を運転し，鉛精鉱の品 位維持に努めることとしている。

亜鉛浮選では，粗選を $\mathrm{pH} 9$ で行っているが，スカル プ浮選を実施しており，スカルプ粗選精鉱はスカルプ精
選を経て直接亜鉛精鉱としている。一方，粗選精鉱は再 磨鉣を含み 3 次精選まで行い, 亜鉛精鉱を採取している。 硫化鉄浮選は，亜鉛清掃選尾鉱をサイクロン分級した アンダーフローを浮選元鉱としている。硫酸で $\mathrm{pH}=4$ に調整し, 粗選から 2 次精選まで行って, 硫化鉄精鉱を 採取している。

硫化鉄粗選尾鉱から，さらに脱硫浮選を行い，重晶石 浮選元鉱としている。重晶石浮選では, ケイ酸ソーダで $\mathrm{pH}=5.5$ とし, 粗選および精選を行って重晶石精鉣を採 取している。

また，スライムシックナーに貯められたスライムは, スライム浮選を行い浮鉱を銅一鉛清掃選に給鉱してい る。

各精鉱をシックナーおよびフィルターで濃縮, 脱水後, 各製錬所にトラック翰送している。また選鉱尾鉣をサイ クロン分級し, 䢸粒はヤードで自然脱水後坑内充填材と して使用している。細粒はさらにサイクロン分級し，ア ンダーフローはフィルターで脱水後坑内充填材として使 用し, 一方オーバーフローは坑内水とともにダムに送泥 している。

磨鉱, 浮選, 精鉱処理工程のフローシートを第 2 困に 示した。 


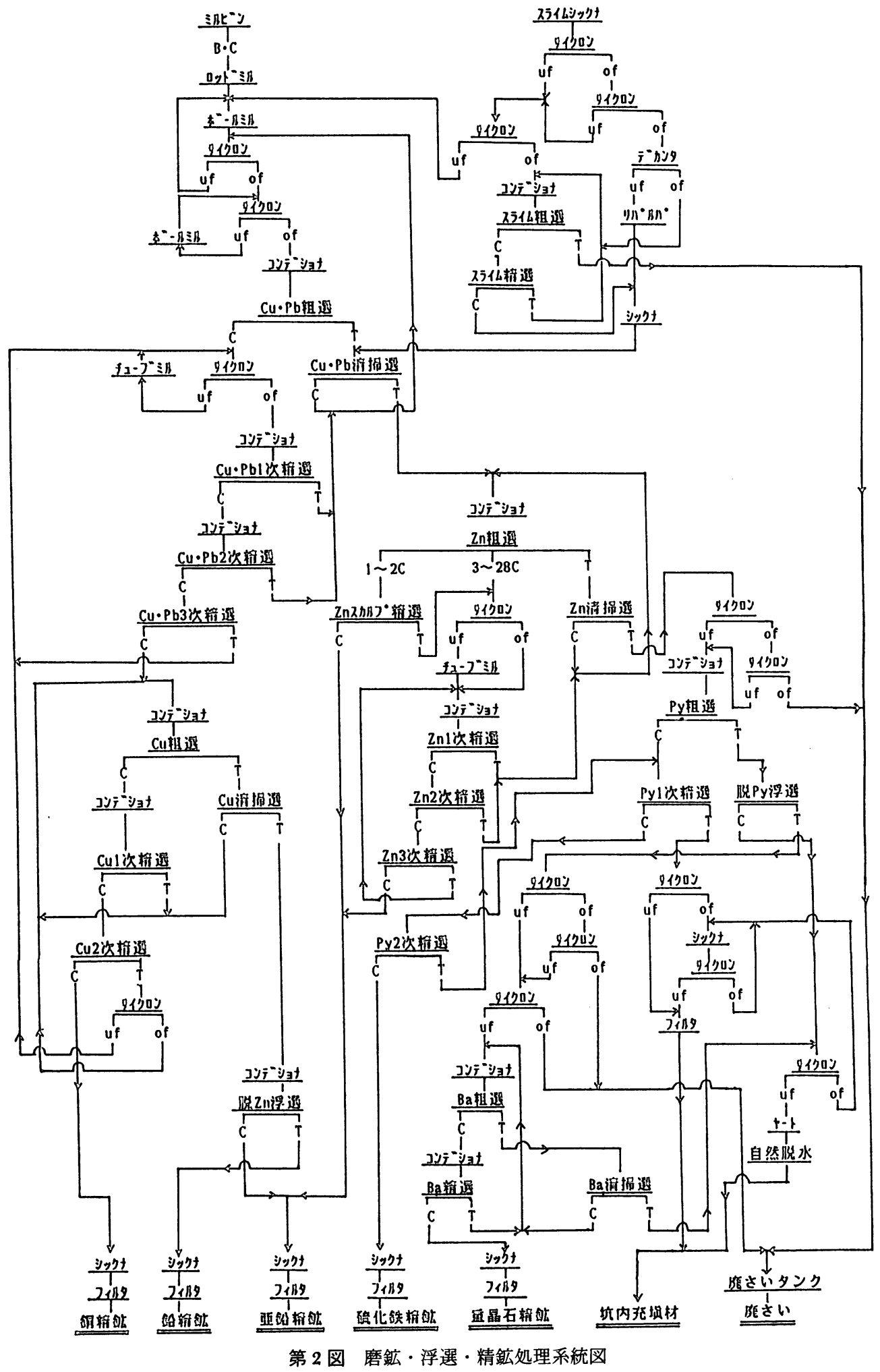




\section{3. 温川鉱の混合処理について}

平成 3 年 3 月の内の岱選鉱工場の操業停止に伴い, 新 内の岱鉱業(温川鉱の混合処理を開始した。その後, 餌釣鉱山の終掘により平成 3 年10月からは松峰, 深沢, 温川鉱の 3 釷種の混合処理を行っている。

混合処理に先たち, 温川鉱の性状を調査し, 花岡鉱 (松 峰鉱十深沢鉣）および混合鉱の浮選試験を実施し，温川 鉱の浮選特性を把握するとともに混合処理が及ぼす影響 を検討した。

\section{1 温川钩の性状について}

（1）温川鉱は, 松峰鉱, 潹沢鉱と比較して金, 銀, 鉛, 亜鉛が高い。

（2）鉱物の $-53 /+37 \mu$ 単体分離度を第 3 表に示した が，温川鉱の方鉛鉱の単体分離度は64.6\% と花岡鉱の $53.3 \%$ に比べて高く，逆に黄鉄鉱のそれは $79.9 \%$ と花岡

第 3 表 単位分離度 $(\%),(-53 /+37 \mu)$

\begin{tabular}{|c|c|c|c|c|c|}
\hline & 銅鉱物 & 方鉊鉱 & 閃严鉊鉱 & 黄鉄鉱 & 眽石 \\
\hline 花岡鉱 & 58.2 & 53.3 & 73.1 & 86.2 & 96.2 \\
\hline 温川鉱 & 44.2 & 64.6 & 71.5 & 79.9 & 96.7 \\
\hline
\end{tabular}

鉱の86.2\%に比べ低い。閃亜鉛鉱，脈石は温川鉱，花岡 鉱ともほぼ同程度の単体分離度となっている。

（3）銅鉱物は黄銅鉱が主体で，他に16\%の四面銅鉱を 含んでいる。

\section{2 温川鉱の浮遊性について}

第 3 図および第 4 表に, 温川鉱, 花岡鉱（松峰鉱と深 沢鉱の混合）および混合鉱（温川鉱，松峰鉱，深沢鉱の 混合）の亜硫酸一消石灰条件による浮選結果を示した。 温川鉱の浮選特性は花岡鉱と比較して

（1）亜硫酸一消石灰条件下では亜鉛が浮きやすく，硫 化鉄は浮き難い。

（2）鉛の浮選速度が遅い。 点があげられた。しかしながら，3 鉱の混合試験では， 亜鉛, 硫化鉄とも温川鉱単独, 花岡鉱単独の場合より抑 制されており，一方鉛の浮遊性は向上した。

以上の点より，温川鉱を花岡鉱と混合処理しても，選 鉱操業上悪影響をおよぼさないと判断した。また温川鉱 を混合処理することによる利点は，鉛の浮遊性の向上が 見込まれること，また操業度向上によるコストの低减が 図れることがあげられた。

平成 3 年 4 月より, 温川鉱を $5,000 \mathrm{~T} /$ 月受け入れ, 混 合処理を開始した。しかしながら，温川鉱は高品位鉱で

第 4 表 温川鉱, 花岡鉱（松峰十深沢鉱）および混合鉱の浮選試験

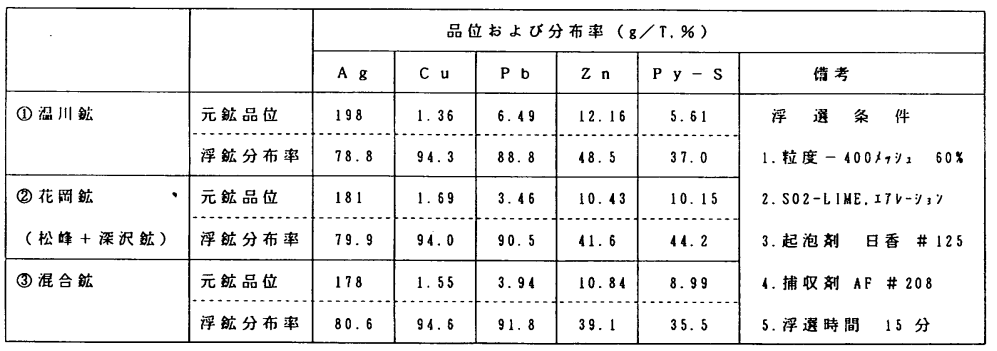

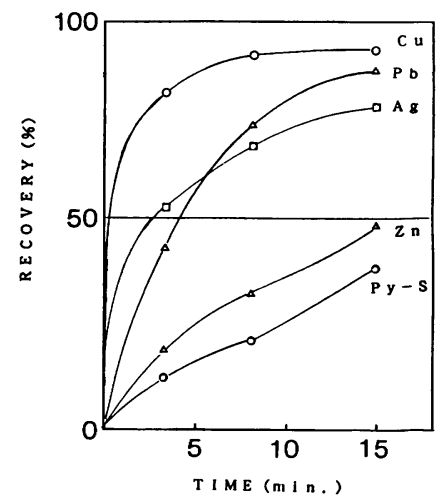

A . 温川矮単独の埸合

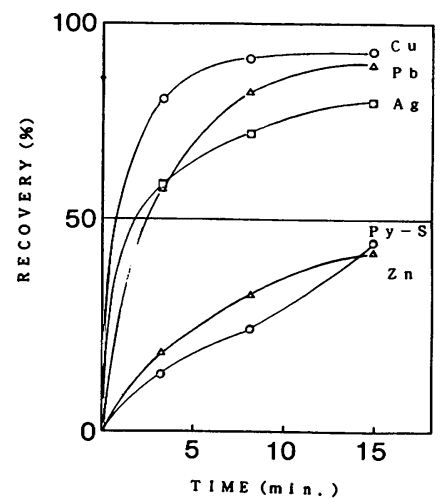

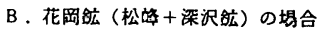

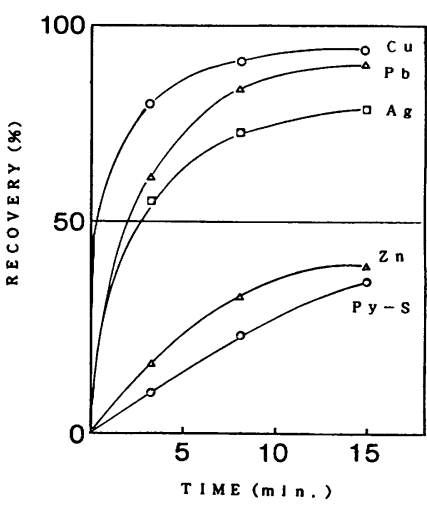

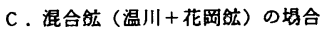

第 3 図 温川鉱, 花岡鉱（松峰十深沢鉱）および混合鉱の浮遊度曲線

Vol. 40, No. 1 ('93-春) 
あるため，平成 4 年 4 月より処理鉱量を減らして 3,800 T/月とし, 現在順調に操業している。

\section{4. ティサパ鉱山の開発について}

同和鉱業(唃は，本年 5 月にメキシコ合衆国において， 現地鉱山会社と共同でティサパ鉱山(橵を設立し，その開 発に取り組んでいる。ティサパ鉱床はメキシコシティー から $270 \mathrm{~km}$ 離れたメキシコ州西部に位置する。

1977年からメキシコ鉱物資源局 (CRM) による広域調 㚗，1979年から精㚗が行われ発見された鉱床である。そ の後, 1987〜90年にかけて金属釷業事業団による調査協 カによって鉱床確認が行われた。鉱床は二畳紀〜三畳紀 の変成岩類中に胚胎する塊状複雑硫化鉱床である。鉱床 の厚さは, 平均 $3.1 \mathrm{~m}$, 最大 $16.25 \mathrm{~m}$, 鉱床の広さは東 西 $600 \mathrm{~m}$, 南北 $500 \mathrm{~m}$ で, 推定埋蔵鉱量は 410 万トンで ある。また，粗鉱品位は $\mathrm{Au} 2 \mathrm{~g} / \mathrm{T}, \mathrm{Ag} 314 \mathrm{~g} / \mathrm{T}, \mathrm{Cu}$ 0.7\%, Pb 1.6\%, Zn 7.9\%である。
各構成鉱物は非常に微細であり,かつ複雑な組織をな しているだめ, 選鉱分離が難しいといら特徽がある。し かしながら，長年黒鉱選鉱で培ってきた技術を駆使する ことにより,この鉱石の選鉱処理は可能といら結論に達 し，ティサバ鉱山の開発に取り組むこととした。

開発計画では, 粗鉱採掘量が月産20,000トン, 亜鉛精 鉱を月産 2,300 トン, 鉰鉛精鉱を月産900トン程度生産し, 生産開始は平成 6 年 4 月を予定している。

\section{5.おわりに}

本報告では黒鉱選鉱工場として現在唯一稼働している 松峰選鉱工場の現況と, ティサパ鉱山の概要について述 べてきたが，今後の厳しい環境に対応するため松峰選鉱 工場では成績の向上と省エネ, 省力化に努めている。

最後に今回の報告にあたり, 日頃ご指導, ご協力いた たいた関係者各位に深く感謝する次第である。 